Filooofia Publiczna i Edukacja Demokratycana

Tom 1 • 2018 • Numer 2 / Tom 8 • 2019 • Numer 1 - Art. \#2 • S. 18-36

DOI: 10.14746/fped.2018.1.2.2019.8.1.2

Www.filozofiapubliczna.amu.edu.pl • ISSN 2299-1875

(c) (reative Commons BY-NC-ND 4.0

\title{
Arystoteles
}

\section{Etyka nikomachejska, Ksiega VI}

\author{
[1. Wypośrodkowanie (to meson) \\ $\mathrm{z}$ trafnym namysłem (orthos logos)]
}

[1138b15] O sprawiedliwości tedy oraz innych cnotach etycznych niech będą rozróżnienia definicyjne podane w ten sposób ${ }^{1}$.

Skoro już wcześniej przypadło nam stwierdzić ${ }^{2}$, że trzeba obierać środek (to meson), a nie nadmiar ani niedomiar, środkiem zaś jest to, co orzeka trafny namysł (orthos logos) ${ }^{3}$, przeto tym się zajmiemy. We wszystkich rzeczonych dyspozycjach (hexeis) ${ }^{4}$, jak i w innych, jest pewien cel (skopos), na który bacząc, ten, kto dysponuje tym namysłem, napina i spuszcza [cięciwę] ${ }^{5}$, gdyż jest pewien zakres (horos) wypośrodkowań, o których mówimy, że zachodzą między nadmiarem i niedomiarem wedle trafnego namysłu.

1 Chodzi o poprzednią, czyli V ks. Etyki nikomachejskiej, do przekładu której odsyłamy, zob. „Księga Arystotelesa O Sprawiedliwości (Eth. Nic. V)", tłum. i oprac. M. Wesoły, Filo-Sofija 2017, nr 36, s. $25-52$.

l O tym mowa w Etyce eudemejskiej II, 1222a3-7.

3 Wyrażenie orthos logos (lac. recta ratio, dictio) oddajemy jako trafny namyst albo trafne określenie czy rozeznanie. Tłumaczenie tego jako stuszna ocena mylnie sugeruje wartościowanie.

4 Hexis (łac. habitus) to dyspozycja-odpowiednio etyczna (związana z charakterem i nawykiem) oraz dianoetyczna (związana z myśleniem, pragnieniem i działaniem).

s Analogia do celowania i strzelania z łuku do tarczy. 
Można to tak orzec prawdziwie, choć może niezbyt jasno. Bo w różnych przedsięwzięciach, o których mamy wiedzę, prawda jest tak orzec, że ani za wiele, ani za mało nie należy czynić, ani zaniechać, ale trzymać się środka, czyli jak podaje trafny namysł. Tyle tylko majac na względzie, nie wiedziałoby się więcej, np. o tym, co ma służyć ciału, jakby ktoś rzekł, że tak zaleca lecznictwo, i tego się trzymać. Dlatego co do tych dyspozycji duszy trzeba to nie tylko uznać za stwierdzone prawdziwie, ale i rozstrzygać, czym jest ten trafny namysł i jaki jest jego zakres.

\section{[2. Działy rozumnej duszy: epistemiczny i kalkulatywny]}

Wyróżniając cnoty (aretai) ${ }^{6}$ duszy, mówiliśmy, że jedne sa cnotami charakteru (ethos), drugie zaś myślenia (dianoia $)^{7}$. [1139a] O tych etycznych już rozważaliśmy, a co do pozostałych, nawiazujacc wpierw do duszy, powiemy w ten sposób. Wcześniej zostało już stwierdzone, że dwa są działy duszy: jeden dysponujący rozumem (to logon echon), drugi nierozumny (to alogon) $)^{8}$. Teraz w tym dysponujacym rozumem trzeba takie poczynić rozróżnienie. Przyjmijmy, że dwa są działy rozumne: jeden, podług którego rozważamy te rzeczy, których zasady (archai) nie mogą mieć się inaczej, drugi zaś ten, podług którego mogą [mieć się inaczej]. Co do rzeczy rodzajowo odrębnych odrębny jest dział duszy względem natury każdego, jeśli przypada im w poznanie według podobieństw i pokrewieństw.

Nazwijmy jeden z nich działem naukowym (to epistemonikon), a drugi kalkulatywnym (to logistikon) ${ }^{9}$. Deliberowanie

6 Arete (łac. virtus) oznacza dosłownie najlepszość czy doskonatość w danym zakresie. Tłumaczymy tradycyjnie - cnota czy zaleta, a nie - dzielność etyczna.

1 Dianoia (łac. mens) oznacza myślenie (Gromska dodaje dyskursywne), wyrażalne w formie językowej twierdzenia lub przeczenia, stąd orzekania prawdy lub fałszu.

8 Rozróżnienie to logon echon - to alogon, w którym rdzeniem jest logos oznaczajacy nie tyle rozum, co właściwie wypowiedź i wywód (stąd aspekt językowo-logiczny w tych wyrażeniach).

9 W polskim przekładzie (Gromska): zdolność poznawania naukowego - zdolność rozumowania. Nie wyraża to istotnej różnicy między poznaniem ściśle naukowym a kalkulowaniem jako deliberowaniem 
bowiem i kalkulowanie (bouleuesthai kai logizesthai) jest tym samym, a nikt nie deliberuje nad tym, co nie może mieć się inaczej; tak też kalkulatywny jest ten dział dysponujący rozumem.

Trzeba tedy uchwycić, jaka w ich obydwu jest najlepsza dyspozycja (hexis); taka bowiem zaleta (arete) każdego, a zaleta odnosi się do właściwego jej dzieła (ergon).

\section{[3. Prawda myślenia - trafność pragnienia]}

Trzy zaś są naczelne w duszy czynniki działania (praxis) i poznawania prawdy (aletheia): postrzeganie (aisthesis), myślenie (dianoia) i pragnienie (orexis). Z nich postrzeganie nie jest w ogóle zaczynem działania; wiadomo, że zwierzęta dysponują postrzeganiem, co z działaniem nie ma związku.

Tak jak w myśleniu jest twierdzenie i przeczenie, tak w pragnieniu dążność i unikanie. Toteż skoro cnota etyczna jest dyspozycją wybierania, wybór (proiresis) zaś obmyślanym pragnieniem, to dzięki temu namysł (logos) winien być prawdziwy, a pragnienie słuszne, jeśli wybór jest dobry, bo to samo się stwierdza i podejmuje. Takie jest tedy myślenie i prawda praktyczna, natomiast w myśleniu teoretycznym, które nie jest praktyczne ani wytwórcze, dobrem lub złem jest prawda lub fałsz (takie zreszta jest dzieło wszelkiego myślenia); prawda zaś myślenia praktycznego i teoretycznego ma się podobnie do trafnego pragnienia.

\section{[4. Wybór (proairesis) i działanie (praxis)]}

Zaczynem (arche) więc działania jest wybór, z którego bierze się ruch, lecz nie jako cel; zaczynem zaś wyboru jest pragnienie i namysł ze względu na cel. Dlatego wybór nie jest bez rozumu i myślenia ani bez dyspozycji etycznej. Wszak dobre działanie i jego przeciwieństwo nie są bez myślenia i charakteru. [1139b] Samo zaś myślenie niczego nie porusza, lecz dany cel i działanie praktyczne. Rządzi też ono wytwarzaniem; dla jakiegoś celu bowiem tworzy każdy wytwórca, a wytwór nie jest celem bezwzględnym, lecz w relacji do

i doradzaniem (bouleuesthai, łac. deliberare, consilari) w dziedzinie praktycznej. 
czegoś i kogoś. Inaczej ma się przedmiot działania; dobre bowiem działanie jest celem, czyli jego pragnieniem. Dlatego wybór jest rozumem (nous) pragnacym albo pragnieniem obmyślanym, a takim jego zaczynem jest człowiek.

Nie można wszak niczego wybrać z tego, co już zaszło, np. nikt nie wybiera zburzenia Troi, bo nikt nie deliberuje nad przeszłościa, lecz tylko nad przyszłością i nad tym, co możliwe; to zaś, co zaszło, nie może się odstać. Dlatego słusznie powiada Agaton ${ }^{10}$ :

«Tego bowiem jednego bóg wyzbyty:

Niebyłe sprawić to, co już się stało».

Dla obydwu działów rozumnych dziełem jest prawda. Najbardziej więc podług tych dyspozycji jedna i druga wyraża prawdę; takie to sa zalety ich obydwu.

\section{[5. Dyspozycje dianoetyczne: wiedza naukowa (episteme)]}

Poczynając więc od powyższych rozróżnień, pomówmy znów o nich. Niech będzie tych pięć dyspozycji, którymi dusza orzeka prawdę w twierdzeniu i przeczeniu. Sa nimi: sztuka (techne $)^{11}$, wiedza naukowa (episteme) ${ }^{12}$, roztropność (phronesis) $)^{13}$, mądrość (sophia) ${ }^{14}$ i intelekcja (nous) ${ }^{15}$. Natomiast w przypuszczaniu (hypolepsis) i mniemaniu (doxa) dopuszcza się orzekanie fałszu.

Otóż czym jest wiedza naukowa, jasne stąd, bo trzeba wyrażać się ściśle, a nie stosować porównań. Wszyscy wszak

10 Agaton - poeta tragik z końca V w. p.n.e. Cytowany dwuwiersz: fr. 5 Dindorf.

"Techne (łac. ars) stanowi dyspozycję wytwórczą (poietike), różną od praktycznej (praktike), choć często bywają mylone.

12 Episteme (łac. scientia), czyli wiedza, ale trzeba tu dodać naukowa. Zob. Marian Wesoły, „Arystotelesowa episteme: przedmiot i metoda”, w: Jan Such, Małgorzata Szcześniak (red.), Z epistemologii wiedzy naukowej, Wydawnictwo Naukowe UAM, Poznań 1998, s. 23-41.

B Phronesis (łac. prudentia) tłumaczymy jako roztropność, a nie jako rozsadek.

14 Sophia (łac. sapientia). Na ten temat por. wywody w Metafizyce (I 2).

is Nous (łac. intellectus) - rozum bądź intelekt. Jako dyspozycja w uchwyceniu pierwszych zasad (archai) stanowi intelekcję, czyli bezpośrednie myślne uchwycenie (simplex apprehensio), czego nie należy mylić z późniejszym pojęciem intuicji. 
zakładamy, że to, co wiemy naukowo, nie może mieć się inaczej [niż jest]. Natomiast to, co może się mieć inaczej, kiedy znajdzie się poza oglądem, nie wiadomo, czy jest czy nie. Z konieczności więc taki jest przedmiot wiedzy naukowej, a zatem jest wieczny; rzeczy bowiem będące z konieczności sa po prostu wszystkie wieczne, a wieczne to niezrodzone i niezniszczalne ${ }^{16}$.

Nadto wszelka wiedza naukowa okazuje się być do wyłożenia, a jej przedmiot do nauczenia. Wszelkie zaś nauczanie wywodzi się z danych uprzednio poznanych, jak o tym mówimy w Analitykach ${ }^{17}$. Zachodzi bowiem przez indukcję (epagoge) i przez sylogizm (syllogismos). Indukcja jest zasadą (arche) tego, co ogólne (to katholou); sylogizm zaś wychodzi z tego, co ogólne. Są zatem przesłanki (archai), z których powstaje sylogizm, a dla których nie ma sylogizmu, lecz tylko indukcja.

Tak więc wiedza naukowa stanowi dyspozycję do dowodzenia (hexis apodeiktike) i dotyczy jej wszystko to, co określiliśmy w Analitykach ${ }^{18}$. Kiedy bowiem ma się odpowiednio

${ }^{16} \mathrm{~W}$ Analitykach wtórych tak to wyraził Stagiryta: „Sądzimy zaś, że poznajemy każdą rzecz bezwzględnie, a nie w sposób sofistyczny według przygodności, kiedy sądzimy, że znamy przyczynę, dzięki której jest ta rzecz, że jest jej przyczyna, i nie może mieć się inaczej. Jasne tedy, że czymś takim jest poznanie naukowe. Jedni bowiem nie poznają naukowo, drudzy zaś poznaja, jedni sądza, że tak rzeczy się maja, inni zaś poznają to naukowo i tak one się mają. Toteż to, o czym właściwie jest wiedza naukowa, nie może mieć się inaczej" (Analityki wtóre I 2, 71b9-6, tłum. M.W.).

" „Wszelkie nauczanie i poznanie rozumowe pochodzi z wiedzy wcześniejszej. Jasne to dla tych, którzy dociekają we wszystkich dziedzinach. Z nauk powstaja w ten sposób te matematyczne i każda z innych sztuk wytwórczych. Podobnie w zakresie argumentów, jedne powstaja przez sylogizmy, inne przez indukcję. Jedne i drugie tworzą nauczanie dzięki danym poznanym wcześniej; jedne biorąc jako zrozumiałe, inne zaś dowodząc ogółu dzięki oczywistości szczegółów. Tak też przekonują argumenty retoryczne: albo poprzez przykłady, czym jest indukcja, albo poprzez entymematy, czym jest sylogizm" (Analityki wtóre I 1, 71a1-11, tłum. M.W.).

18 „Dowodem nazywam sylogizm epistemiczny; epistemicznym zaś nazywam ten, poprzez posiadanie którego poznajemy naukowo. Jeśli tedy poznanie naukowe jest takie, jak założyliśmy, to wiedza demonstratywna musi być z [przesłanek] prawdziwych, pierwszych i bezpośrednich, lepiej znanych i jako przyczyn wniosku. Tak bowiem będa się miały zasady właściwe dla dowodzonego przedmiotu. Sylogizm 
pewność i znane sa zasady, wtedy poznaje się naukowo. Jeśli zaś nie zna się ich lepiej od wniosku, wiedza będzie w sensie przygodnym (kata symbebekos). Wiedzę naukową określa się więc w ten sposób.

\section{[6. Sztuka (techne)]}

[1140a] Z tego zaś, co może mieć się inaczej, jest coś do wytworzenia i do zdziałania. Czym innym jest wszak tworzenie (poiesis) i działanie (praxis); traktujemy też o tym w popularnych wykładach ${ }^{19}$. Toteż dyspozycja wraz z namysłem (meta logou) do działania jest czymś różnym od dyspozycji wraz z namysłem do tworzenia. Dlatego nie obejmuja siebie wzajemnie, bo ani działanie nie jest tworzeniem, ani tworzenie działaniem. Skoro budownictwo jest pewną sztuka i pewną dyspozycją z namysłem do tworzenia, a żadna sztuka nie jest taka, co nie byłaby z namysłem dyspozycja do tworzenia, ani taka, co nie byłaby sztuka, tym samym będzie sztuka i dyspozycja wraz z prawdziwym namysłem do tworzenia.

Otóż wszelka sztuka dotyczy powstawania, stanowi projektowanie i rozważanie, w jaki sposób powstaje coś z rzeczy mogacych być lub nie być i których zaczyn (arche) jest w wytwarzajacym, a nie w wytworze. Nie dotyczy bowiem sztuka rzeczy z konieczności będących lub stających się ani tych podług natury, gdyż te mają swą zasadę w sobie samych. Skoro zaś tworzenie i działanie jest czymś odrębnym, to musi sztuka dotyczyć tworzenia, a nie działania.

W pewien sposób tego samego dotyczą przygodność (tyche) i sztuka, jak powiada Agaton ${ }^{20}$ :

«Sztuka przygodność umiłowała, a przygodność sztukę».

Sztuka więc, jak powiedziano, jest pewna dyspozycja wraz z namysłem do tworzenia; nieumiejętność zaś w sztuce (atechnia) - przeciwnie, dyspozycją wraz z mylnym namysłem w tworzeniu, w zakresie tego, co może mieć się inaczej.

będzie i bez nich, dowód zaś nie, gdyż nie wytworzy wiedzy naukowej" (Analityki wtóre I 2, 71b17-25, tłum. M.W.).

19 Exoterikoi logoi-zapewne popularne wykłady czy wywody przeznaczone dla szerszej publiczności.

${ }^{10}$ Agaton, fr. 6 Dindorf. 


\section{[7. Roztropność (phronesis)]}

Co tyczy się zaś roztropności, ujmijmy ją w ten sposób, rozważając, jakie to osoby nazywamy roztropnymi. Wydaje się być roztropnym ten, kto potrafi snadnie deliberować (bouleuesthai) nad tym, co jest dlań dobre i pożyteczne, nie po części, np. co do zdrowia czy siły, lecz w ogóle co do dobrego życia. Oznaka zaś tego, że roztropnymi nazywamy też tych w jakimś zakresie, gdy względem jakiegoś szczytnego celu dobrze kalkuluja, ale nie z dziedziny sztuki. Toteż ogólnie byłby roztropny ten, kto potrafi deliberować.

Nikt jednak nie deliberuje nad tym, co nie może mieć się inaczej, ani nad tym, co niemożliwe sprawić. Toteż skoro wiedza naukowa dotyczy dowodzenia, przy czym jej zasady nie moga mieć się inaczej, a o nich nie ma dowodzenia (bo wszystkie mogłyby mieć się inaczej), i nie można deliberować nad tym, co zachodzi z konieczności, [1140b] to roztropność nie będzie ani wiedzą naukowa, ani sztuka; wiedzą naukową dlatego nie, że przedmiot działania może się mieć inaczej; sztuką zaś dlatego nie, bo inny jest rodzaj działania i tworzenia. Odrębny jest bowiem cel tworzenia, działania zaś taki nie jest, gdyż samo dobre działanie jest celem. Pozostaje więc to, że roztropność jest dyspozycją prawdziwą wraz z namysłem, praktyczną co do ludzkiego dobra i zła.

Dlatego sązimy, że Perykles ${ }^{21}$ i tacy jak on sa roztropni, ponieważ potrafią rozważyć, co dla nich samych i dla ludzi jest dobre. Uważamy, że takimi są właśnie gospodarze i politycy.

Stąd umiarkowanie (sophrosyne) określamy tą nazwa, jako że jest zachowujacce roztropność (sodzousan ten phronesin), zachowuje jej ujęcie (hypolepsis) ${ }^{22}$. Bo nie każde ujęcie zanika i odwraca przyjemność i przykrość, jak np. to, że trójkąt ma bądź nie wewnętrznie kąty równe dwom prostym, lecz tylko takie dotyczace działania. Zasadami bowiem działań praktycznych jest cel tych działań. Kogo jednak zwiodła przyjemność czy przykrość, temu wnet nie jawi się ta zasada

" Perykles (ok. 495-429 p.n.e.) - ateński mąż stanu, uznany tutaj jako wzorcowy phronimos.

n Pozorna etymologia oparta na grze słów trudnej do oddania w przekładzie. To samo podaje Platon w Kratylosie (411e4-412a8): „Umiarkowanie to zachowanie roztropności”. 
ani to, że należy wszystko w tym czy tamtym celu wybierać i działać. Albowiem nikczemność (kakia) jest tym, co niweczy daną zasadę. Toteż z konieczności roztropność jest dyspozycją praktyczna podług namysłu prawdziwą co do ludzkich dóbr.

Wszelako co do sztuki jest pewne mistrzostwo (arete), a co do roztropności takiego nie ma. W sztuce kto umyślnie bładzi, bywa bardziej uznany, w roztropności zaś mniej, jako też w zakresie cnót. Jasne tedy, że jest ona sama jaką́s cnota, a nie sztuką.

Spośród dwu rozumnych działów duszy roztropność byłaby cnota w zakresie mniemania (doxastikon); mniemanie bowiem odnosi się do tego, co może mieć się inaczej, i taka jest roztropność. Wszak nie jest to tylko dyspozycja wraz z namysłem; oznaką tego jest możliwość zatracenia tamtej dyspozycji, co do roztropności zaś tego nie ma.

\section{[8. Zasady wiedzy naukowej uchwytne intelekcją (nous)]}

Skoro wiedza naukowa jest ujęciem tego, co ogólne i co zachodzi z konieczności, istnieją zaś zasady (archai) dowodzeń i całej wiedzy naukowej (z wnioskowaniem bowiem wiaże się ta wiedza), to zasadą przedmiotu wiedzy naukowej nie może być ani wiedza naukowa, ani sztuka, ani roztropność. Wszak przedmiot wiedzy naukowej jest demonstratywny, a tamte dopuszczają też to, co może mieć się inaczej. [1141a] Mądrość także nie jest ich przedmiotem, gdyż cechą mędrca jest to, że w pewnych sprawach dysponuje dowodem.

Jeśli zatem w tym wypowiadamy prawdę i nie mylimy się względem tego, co nie może lub może mieć się inaczej, a tym jest wiedza naukowa, roztropność, mądrość i intelekcja, z tych zaś trzech dyspozycji żadna nie może tym być (mam na myśli te trzy: roztropność, wiedzę naukową i mądrość), to pozostaje przyjać, że intelekcja ma za przedmiot owe zasady.

\section{[9. Mądrość (sophia) a roztropność]}

Mądrość w sztukach przypisujemy tym najzdolniejszym artystom, co tworzą sztuki, na przykład Fidiasz ${ }^{23}$ jest mądrym

\footnotetext{
B Fidiasz (ok. 490-431 p.n.e.) - słynny ateński twórca Partenonu.
} 
rzeźbiarzem w marmurze, a Poliklet ${ }^{24}$ mądrym rzeźbiarzem w brąie, stąd nic innego nie oznaczamy przez 'mądrość' jak właśnie mistrzostwo (arete) sztuki. Sądzimy zaś, że niektórzy mądrzy są w ogóle, nie po części ani jakoś inaczej mądrzy, jak Homer rzecze w Margitesie ${ }^{25}$ :

"Ani hodowca, ani oraczem bogowie go uczynili,

Ni w niczym innym mądrym».

Toteż wiadomo, że najdoskonalszą z nauk byłaby mądrość. Mędrzec winien tedy nie tylko znać wnioski wynikajace z zasad, ale i orzec o prawdziwości tych zasad. Mądrość byłaby zatem intelekcja wraz $\mathrm{z}$ wiedzą naukowa, niejako zwieńczeniem wiedzy naukowej o rzeczach najbardziej szacownych. Niedorzeczne bowiem, jeśli ktoś sądzi, że polityka czy roztropność jest najwartościowsza, skoro człowiek nie jest kimś najlepszym w kosmosie.

Bo jeśli zdrowie i dobro czym innym jest dla ludzi i ryb, to zaś, co białe i proste, wciąż tym samym, tak i to, co mądre, wszyscy nazwaliby tym samym, natomiast to, co roztropne, czymśs różnym. Tego bowiem nazwałoby się roztropnym, kto dobrze wszystko o sobie rozważa, i jemu się powierzy te sprawy. Stąd powiadaja, że i niektóre zwierzęta sa roztropne, te, co zdają się mieć zdolność przewidywania związana z ich życiem.

To jasne, że mądrość i polityka nie byłyby tym samym. Jeśli zaś [ludzie] nazywają mądrością tę dotycząca korzyści dla nich samych, to liczne będą mądrości: nie tylko jedna dla dobra wszystkich, lecz różne dla każdego, bo nie ma też jednej sztuki lekarskiej dla wszystkich. Jeśli zaś przyjać, że człowiek jest najlepszy ze wszystkich stworzeń, nie czyni to różnicy, bo i od człowieka inne byty z natury sa bardziej boskie, jak te najbardziej świetliste, z których składa się kosmos.

[1141b] Z tego, co powiedziano, jasno wynika, że mądrościa jest i wiedza naukowa, i intelekcja rzeczy najszacowniejszych z natury. Dlatego o Anaksagorasie i Talesie ${ }^{26}$ i takich mędrcach nie mówi się, że są roztropni, skoro widzi

${ }^{14}$ Poliklet (aktywny w latach 460-420 p.n.e.) - słynny rzeźbiarz, twórca posagu Doryforosa i kanonu proporcji ciała ludzkiego.

Is Niezachowany poemat Margites przypisywany Homerowi, fr. 2 Allen.

${ }^{16}$ Tales i Anaksagoras to przykłady mędrców oddanych bezinteresownie badaniom i nauce. 
się ich zaniedbujących własne korzyści, a oni sami powiadaja, że znają rzeczy niezwykłe, cudowne, trudne i boskie, choć nieużyteczne, jako że o ludzkie dobra nie zabiegaja.

\section{[10. Roztropność względem ogółu i szczegółów]}

Roztropność wszak dotyczy spraw ludzkich i tych, nad którymi można deliberować (bouleuesthai); mówimy, że dla kogoś roztropnego to jest szczególnym zadaniem: dobrze deliberować, a nikt nie deliberuje nad tym, co nie może mieć się inaczej, ani nad tym, co nie ma żadnego celu, a celem tym jest właśnie dobro praktyczne. Kto bezwzględnie dobrze deliberuje, jest kimś celującym w najlepsze z dóbr praktycznych dla człowieka podług wyrozumowania (logismos).

Roztropność nie dotyczy tylko tego, co ogólne, lecz trzeba też rozpoznać to, co jednostkowe (kath'hekasta) ${ }^{27}$; jest bowiem praktyczna, a działanie dotyczy spraw jednostkowych. Stąd niektórzy, nie znając tego, co ogólne, są bardziej praktyczni, jak w innych dziedzinach ci doświadczeni. Bo gdyby ktoś wiedział, że lekkie potrawy mięsne są łatwo strawne i zdrowe, a nie wiedział, które są lekkie, nie sprawi zdrowia, lecz raczej ten, kto wie, że drób jest lekki i zdrowy. Roztropność jest praktyczna, toteż trzeba opanować je obydwie [ogólną i szczegółowa], zwłaszcza tę drugą. Jedna $\mathrm{z}$ nich byłaby w tym bardziej przewodnia.

\section{[11. Polityka a roztropność]}

Polityka i roztropność jest właściwie tą samą dyspozycją (hexis), chociaż ich istota nie jest taka sama. Ta dotyczaca państwa (polis) jako wiodacca stanowi prawodawstwo (nomothetike); tamta zaś w zakresie spraw jednostkowych ma wspólną nazwę polityki. Jest ona praktyczna i doradcza (bouleutike). Uchwała bowiem dotyczy praktyki jako konkretu (to eschaton). Stąd mówi się, że uprawiają politykę tylko ci [wykonawcy uchwał], bo jedynie oni postępują tak jak rękodzielnicy.

"To kath'hekaston - to eschaton. Trudne do przełożenia dwa zbieżne treściowo wyrażenia: szczegót - konkret, czyli to, co ostatecz$n e$ (w percepcji czy intelekcji). 
Wydaje się, że roztropność jest najbardziej tym, co dotyczy poszczególnych jednostek. Ona też ma wspólną nazwę - roztropność. Z tamtych zaś jedna stanowi ekonomię (oikonomia), druga zaś prawodawstwo (nomothesia), inna to polityka, w której jedna jest doradztwem (bouleutike), a druga sądownictwem (dikastike).

\section{[12. Roztropność i percepcja konkretów]}

Pewną więc forma poznania byłaby wiedza co do własnego dobra, lecz różni się ona znacznie. [1142a] Wydaje się, że kto poznaje i doświadcza własne sprawy, jest roztropny, chociaż politycy zajmują się wieloma sprawami. Dlatego Eurypides powiada ${ }^{28}$ :

«Jak mam tu być roztropny, gdzie stoję bezczynnie,

Jak jeden z wielu w szeregu wojska

Na równo mający udział.

Ci bowiem, co mogą więcej, coś czyniąc, mają przewagę».

Poszukują bowiem swego własnego dobra i sądza, że trzeba tak czynić. Z takiego poglądu wynika, że są roztropni, choć chyba nie ma własnego dobra bez rodziny i bez wspólnoty politycznej. A zreszta jak należy o nie zabiegać, jest niejasne i wymaga zbadania.

O tym, co powiedziano, świadczy też to, że młodzi bywaja znawcami geometrii i matematyki i mądrzy sa w tym przedmiocie, jednak nie wydaje się, że bywają roztropni. Przyczyna tego taka, że roztropność dotyczy spraw jednostkowych, które poznaje się z doświadczenia, a młodzieniec doświadczony nie jest (skoro przez dłuższy czas nabywa się doświadczenie). Spytałby ktoś, dlaczego chłopiec może zostać matematykiem, ale nie mędrcem czy przyrodnikiem. Czy dlatego, że jedne zasady bierze się z abstrakcji, drugie zaś z doświadczenia, a młodzi co do jednych nie muszą mieć pewności, tylko je wyrażaja, a co do drugich istota rzeczy jest im niejawna?

Ponadto błąd w deliberowaniu dotyczy albo tego, co ogólne, albo tego, co jednostkowe, np. albo tego, że wszystkie wody ciężkie sa szkodliwe, albo że ta oto woda jest ciężka.

Że roztropność nie jest wiedzą naukowa, to jasne. Dotyczy bowiem tego, co konkretne (to eschaton), jak wspomniano.

\footnotetext{
18 Fragment (787 i 788 Nauk) z Filokteta Eurypidesa.
} 
Czymś takim jest przedmiot działania (to prakton). Przeciwstawne jest to intelekcji (nous); intelekcja bowiem dotyczy terminów definicji (horoi), co do których nie ma dowodu (logos), a roztropność dotyczy konkretu, co do którego nie ma wiedzy naukowej, lecz percepcja (aisthesis), ale nie własnych przedmiotów zmysłowych, tylko tego, czym spostrzegamy, że w matematyce konkretem jest trójkąt; na nim bowiem [percepcja] się zatrzymuje. Lecz ta jest bardziej percepcją aniżeli roztropność, dla tej zaś jest inna forma [percepcji].

\section{[13. Dobra porada (euboulia) - trafność namysłu]}

Dociekanie (to zetein) zaś i deliberowanie (to bouleuesthai) różnią się, choć deliberowanie jest pewnym dociekaniem. Trzeba tu uchwycić, czym jest dobra porada ${ }^{29}$, czy jest jaką́s wiedzą naukowa, mniemaniem, bystrością (eustochia) czy jeszcze czymś innym.

Wiedzą naukową nie jest (nie docieka się bowiem tego, o czym się już wie), a dobra porada jest pewnym deliberowaniem; ten zaś, kto deliberuje, docieka czegoś i kalkuluje. [1142b] Lecz nie jest też bystrościa; bez namysłu bowiem i szybko wyraża się bystrość, a deliberuje się dłuższy czas, choć powiadaja, że należy szybko zdziałać to, co doradzone, choć doradza się powoli.

Zresztą dobra porada jest czymś różnym od przemyślności (anchinoia); przemyślność zaś jest jakąśs bystrościa.

Dobra porada nie jest też żadnym mniemaniem (doxa). Bo skoro źle doradzający jest w błędzie, kto zaś dobrze doradza, ten czyni to trafnie, stąd jasne, że dobra porada jest pewną trafnościa (orthotes), ale nie wiedzy naukowej ani mniemania. Nie jest bowiem trafnością wiedzy naukowej (ani też błądzeniem); trafnością zaś mniemania jest prawdziwość (aletheia), zarazem też określone już jest wszystko to, co dotyczy mniemania. Jednakże nie ma dobrej porady bez namysłu (aneu logou).

Pozostaje zatem, że jest trafnościa myślenia (dianoia). Ta bowiem jeszcze nie jest stwierdzeniem (phasis). Albowiem mniemanie nie jest dociekaniem, lecz już jakimś

\footnotetext{
29 Euboulia - dobra porada, a nie dobry namyst czy zaradność.
} 
stwierdzeniem. Doradzajacy zaś - czy to dobrze, czy źle deliberuje, docieka czegoś i kalkuluje. Otóż dobra porada jest pewną trafnościa doradzania. Dlatego trzeba wpierw zbadać, czym jest porada i czego dotyczy.

Skoro zaś trafność ma wiele znaczeń, to jasne, że jest nią nie każda [dobra porada]. Ktoś bowiem nieopanowany i marny osiagnie to, do czego zmierzał w swej kalkulacji (ek tou logismou), toteż niby trafnie doradzając, będzie sprawiał wielkie zło. Wydaje się zaś czymś dobrym dobre doradzanie. Taka właśnie trafność porady jest dobra porada, nastawiona na dobro. Lecz można to osiagnać i fałszywym sylogizmem i uzyskać to, co trzeba czynić, ale nie wyjaśnić 'dlaczego', bo fałszywy jest tutaj termin średni. Toteż nie jest to jakaś dobra porada, podług której osiaga się coś, czego jednak nie należało.

A zresztą można osiagnąć coś po dłuższej deliberacji, coś innego zaś szybko. Otóż nie taka jest jeszcze dobra porada, lecz trafność podług tego, co pożyteczne, i tego, co trzeba, jak i kiedy. Ponadto można też całkiem dobrze deliberować wokół jakiegoś celu. Taka właśnie całkiem dobra deliberacja wokół celu jest całkiem prawidłowa, a pewna szczególna deliberacja względem celu szczegółowego.

Jeśli tedy dobre deliberowanie należy do roztropnych, to dobra porada byłaby trafnością podług pożytku względem danego celu, którego roztropność jest prawdziwym ujęciem (hypolepsis).

\section{[14. Pojętność (synesis) i rozwaga (gnome)]}

Pojętność zaś i dobra pojętność (eusynesia), podług których nazywamy ludzi pojętnymi i dobrze pojętnymi, [1143a] nie sa zupełnie tym samym co wiedza naukowa i mniemanie (bo wszyscy byliby pojętni), ani też żadną z nauk szczegółowych, jak lecznictwo traktujące o zdrowiu czy geometria o wielkościach. Pojętność bowiem nie dotyczy rzeczy będących zawsze i niezmiennych ani tych stajacych się jakoś, lecz tylko tych, co do których można mieć wątpliwości i deliberować. Stąd pojętność dotyczy tego samego co roztropność, choć nie jest tym samym pojętność i roztropność. Roztropność bowiem jest zalecajacca (epitaktike) (co należy czynić lub nie, a co jest jej celem), pojętność zaś jest tylko rozsądzająca 
(kritike). Tym samym jest pojętność i dobra pojętność oraz ludzie pojętni i dobrze pojętni.

Pojętność nie jest posiadaniem roztropności ani jej nabywaniem, lecz jak uczenie się oznacza pojmowanie, kiedy posługuje się wiedza, tak w posługiwaniu się mniemaniem przy rozsądzaniu tego, o czym traktuje roztropność. Inaczej mówiąc, przy pięknym rozsądzaniu tego, dobrze bowiem to tyle co snadnie. Stąd wzięła się nazwa 'pojętność', podług której ludzie są dobrze pojętni w uczeniu się; często bowiem uczenie się nazywamy pojmowaniem.

Tak zwana rozwaga (gnome), podług której mówimy, że jesteśmy dobrze rozważni i mamy wyrozumiałość (syngno$m e)^{30}$, jest trafnym rozsądzaniem (krisis orthe) przez kogoś łagodnego (epieikes). Świadczy o tym to, że o kimś iście łagodnym mówimy, iż jest wyrozumiały, a łagodność to posiadanie w pewnych sprawach wyrozumiałości. Wyrozumiałość jako rozwaga jest trafnym rozsądzaniem ze strony kogoś łagodnego. Trafne to takie, co jest wyrazem prawdziwości.

\section{[15. Pojętność, rozwaga, roztropność i intelekcja dotyczą konkretów]}

Wszystkie te dyspozycje zmierzają zasadnie do tego samego; mówimy bowiem o rozwadze, pojętności, roztropności i intelekcji, odnosząc do tych samych osób posiadanie rozwagi i intelekcji, tudzież bycie roztropnymi i pojętnymi. Wszystkie te zdolności dotyczą bowiem konkretów (ta eschata) i spraw jednostkowych (kath'hekaston) i w czym kto jest rozsądzający (kritikos), w tym jest też roztropny, pojętny i rozważny czy wyrozumiały. Łagodne bowiem działania są wspólne dla wszystkich dobrych ludzi w stosunku do kogoś innego.

Wszelkie zaś działania należą do spraw jednostkowych i konkretnych i ktoś roztropny winien je rozpoznawać, a pojętność i rozwaga dotyczy tych działań, które są konkretne.

Także intelekcja (nous) dotyczy konkretów w obydwu przypadkach: bo i o pierwszych terminach (protoi horoi)

${ }^{30}$ Gnome i złożenie syngnome - trudne do wyrażenia w przekładzie: rozwaga-wyrozumiatość. 
i o konkretach stanowi intelekcja [1143b], a nie wnioskowanie (logos), i tak w jednym przypadku ona podług dowodzeń dotyczy niezmiennych i pierwszych terminów, w drugim zaś w działaniach praktycznych konkretu i możliwości, i drugiej przesłanki. Takie to sa zasady (archai) celu, do którego się dąży; ze szczegółów bowiem bierze się ogół. O tych więc trzeba mieć percepcję (aisthesis), która jest intelekcja. Stąd zdaja się to być zdolności naturalne, choć z natury nikt nie jest mądry, by mieć rozwagę, pojętność i intelekcję.

Świadczy o tym to, że sądzimy, iż następują one z wiekiem, i w takim wieku ma się już intelekcję i rozwagę, jako że sprawstwem tego jest natura. Stąd początkiem (arche) i końcem (telos) jest intelekcja; z nich bowiem sa dowody (apodeixeis) oraz ich dotycza. Toteż trzeba zważać, nie mniej od dowodów, na niedowodliwe wypowiedzi i poglądy ludzi doświadczonych i starszych, czyli roztropnych. Bo dzięki posiadaniu 'oka' na podstawie doświadczenia postrzegają oni trafnie.

\section{[16. Pożytek z roztropności i mądrości]}

Czym więc jest roztropność i czym mądrość oraz czego jedna i druga dotyczy i że innego działu duszy jest cnota każdej z nich, o tym zostało powiedziane.

Mógłby jednak ktoś mieć wątpliwość, w czym są one pożyteczne. Mądrość bowiem nie rozważa tego, z czego poczynając, człowiek będzie szczęśliwy (nie dotyczy wszak żadnego stawania się), a roztropność ma to za przedmiot, lecz po cóż ona nam potrzebna? Skoro roztropność dotyczy spraw prawych, pięknych i dobrych dla człowieka, a te sa tymi, które ma czynić człek dobry, to w niczym bardziej skłonni do działania nie będziemy z samego ich poznania, jeśli cnoty sa dyspozycjami. To samo odnosi się do rzeczy zdrowych i dobrego stanu, które się określa nie ich sprawianiem, lecz dysponowaniem. Nie staniemy się bowiem bardziej skłonni do działania z samego władania wiedzą medyczną i gimnastyczna.

Jeśli zaś nie dzięki nim trzeba uznać kogoś roztropnym, ale przez stawanie się, to dla osób wartościowych nie byłoby to potrzebne, ani zresztą dla tych, którzy nimi nie sa. Nie odróżni się tego, czy oni ją maja, od przekonania innych, że ją maja. Wystarczyłoby to nam, jak w wypadku zdrowia; chcemy przecież być zdrowi, choć nie uczymy się lecznictwa. 
W związku z tym niedorzeczne byłoby mniemać, że roztropność, choć pośledniejsza od mądrości, będzie dla niej nadrzędna (kyriotera); ta bowiem jako sprawiająca rządzi i nakazuje we wszystkim. O tym jeszcze trzeba powiedzieć; na razie tylko wysunięte zostały wątpliwości.

\section{[17. Roztropność a cnoty etyczne]}

[1144a] Najpierw tedy mówimy, że same w sobie musza być godne wyboru, będąc cnotami (aretai) jednego i drugiego działu duszy, nawet jeśli żadna z nich niczego nie sprawia.

Następnie mówimy, że jednak coś sprawiaja; nie tak jak lecznictwo zdrowie, lecz tak jak samo zdrowie, tak też mądrość sprawia szczęśliwość (eudaimonia). Będąc bowiem działem całej cnoty, swym dysponowaniem i działaniem sprawia kogoś szczęśliwym.

Ponadto działanie to spełnia się podług roztropności i cnoty etycznej, albowiem cnota czyni trafnym cel (skopos), a roztropność do niego prowadzi.

W czwartym zaś dziale duszy nie ma takiej cnoty, czyli w dziale żywiennym (threptike), bo nie ma w nim praktycznego działania (prattein) czy niedziałania ${ }^{31}$.

W związku z tym, że przez samą roztropność nie bywamy bardziej praktyczni w czynach pięknych i prawych, trzeba wyjść od tego, co powyżej, przyjmując taką zasadę. Jak bowiem mówimy, że niektórzy, choć podejmuja prawe czyny, nie sa jeszcze prawymi, np. ci, co czynią rzeczy nakazane przez prawa niedobrowolnie czy z niewiedzy, czy czegoś innego, a nie dla nich samych (choć czynią to, co należy i co powinien ktoś wartościowy), tak też - jak się zdaje - można wszystko tak czynić, aby było dobre; powiadam, np. z wyboru i mając na celu podjęcie samych działań. Trafny więc wybór czyni tu cnota, to zaś, co dla niej przypada sprawić, nie należy do cnoty, ale do innej zdolności (dynamis). Trzeba jednak poznawczo wyrazić się o tym jaśniej.

"Cztery części duszy: zmysłowa, rozumna, pożądliwa i żywienna (wegetatywna). Na temat tej ostatniej zob. M. Wesoły, „Dusza żywienna (wegetatywna) zwierząt w koncepcji Arystotelesa”, w: Kazimierz Ilski (red.), Człowiek w świecie zwierzat - zwierzęta w świecie człowieka, Wydawnictwo Naukowe UAM, Poznań 2012, s. 87-106. 
Otóż jest pewna zdolność, którą nazywają sprytem (deinotes); ona jest taka, że do osiagnięcia założonego celu zdoła urzeczywistnić podjęte działania. Jeśli więc cel jest piękny, godne to pochwały, jeśli zaś marny, to stanowi chytrość

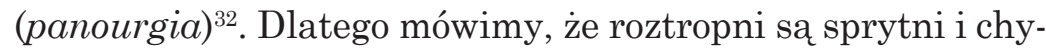
trzy. Wszelako roztropność to nie taka zdolność, choć nie jest bez takiej zdolności.

Snadź dyspozycja ta nie powstaje w tym 'oku' duszy bez cnoty, jak powiedziano, i to jest jasne. Albowiem sylogizmy dotyczace działań praktycznych mają taką zasadę: 'skoro taki to jest cel i to, co najlepsze', czymkolwiek będąc, niech będzie dla przykładu tym, co się nadarza. Tak zaś wydaje się tylko komuś godziwemu; nikczemność bowiem to odwraca i czyni zafałszowanie co do zasad praktycznych. Toteż jasne, że nie można być roztropnym, nie będąc godziwym.

\section{[18. Cnota naturalna (physike) i naczelna (kyria) względem roztropności]}

[1144b] Trzeba tu znów rozważyć o cnocie. Cnota bowiem ma się analogicznie jak roztropność do sprytu (nie tak samo, lecz podobnie), tak też naturalna cnota ma się do głównej (kyria). Wszystkim bowiem wydaje się, że każdy z charakterów przypada jakoś z natury, bo prawi, umiarkowani i dzielni jesteśmy i inne zalety mamy zaraz od urodzenia. Dociekamy jednak jakiegoś innego i naczelnego dobra (agathon), a te zdolności przypadaja nam w inny sposób, bo i dzieciom, i zwierzętom przysługują naturalne dyspozycje, lecz bez rozumu (nous) okazują się być szkodliwe.

Prócz tego można zauważyć, że jak silnemu ciału bez kierowania wzrokiem przypada okropnie błądzić wskutek nieposiadania wzroku, takoż i tutaj; gdy ktoś nabierze rozumu, w działaniu się wyróżni. Dyspozycja ta podobna będzie wtedy do nadrzędnej cnoty.

Tak jak w tym sa dwie formy działu mniemania (doxastikon): spryt i roztropność, tak też są dwie w dziale etycznym:

3 Pokrewne wyrażenia Arystotelesa tak tłumaczymy: bystrość (eustochia), przemyślność (anchinoia), spryt (deinotes), przebiegłość (panourgia). 
cnota naturalna i naczelna, i z nich ta naczelna nie powstaje bez roztropności.

\section{[19. Sokrates o roztropności mylnie i trafnie]}

Dlatego niektórzy powiadaja, że wszystkie cnoty sa formami roztropności, a Sokrates w jednym trafnie tego dociekał, w drugim zaś się mylił. Że wszelkie cnoty są formami roztropności, mylił się, że zaś nie istnieją bez roztropności, pięknie to głosił.

Oznaka tego zaś taka, bo teraz wszyscy, gdy definiuja cnotę, dodają tę dyspozycję, mówiąc tė̇, względem czego jest ona podług trafnego namysłu (orthos logos), a trafne jest to, co podług roztropności. Wszyscy zdają się jakoś wyczuwać, że taka dyspozycja jest cnota, ta podług roztropności.

Trzeba to nieco zmodyfikować. Nie tylko bowiem podług trafnego namysłu, lecz wraz z trafnym namysłem cnota jest dyspozycja. Trafnym zaś co do tego namysłem jest roztropność. Sokrates sądził zatem, że namysłami (logoi) są cnoty (naukami są bowiem wszystkie), my zaś sądzimy, że wraz z namysłem (meta logou).

Jasne więc z tego, co powiedziano, że nie można być właściwie dobrym bez roztropności ani roztropnym bez cnoty etycznej.

\section{[20. Roztropność pośród cnót]}

Lecz argument ten można by i w tym rozstrzygnać, gdyby ktoś wywodził, że cnoty rozłączne są wzajemnie; ten sam człowiek nie jest z natury najbardziej podatny na wszystkie, toteż jedną już by miał, drugiej jeszcze nie. To jednak możliwe podług cnót naturalnych, podług zaś których zwie się ktoś bezwzględnie dobrym, to niemożliwe. [1145a] Łącznie bowiem z jedną roztropnością występować będą wszystkie cnoty.

Jasne więc, że gdyby nie była ona praktyczna, zachodziłaby jej potrzeba wskutek tego, że jest cnotą rozumnego działu duszy i że nie będzie trafnego wyboru bez roztropności ani bez cnoty. Jedna bowiem stanowi cel, a druga względem celu sprawia działanie. 
36| Arrsitoteles |

Jednak roztropność nie jest panujaca nad mądrością ani nad lepszym działem duszy, jak lecznictwo nie jest nad zdrowiem. Nie posługuje się nia, lecz postrzega, jak się staje; ze względu na nią rozporządza, ale nie dla niej. Zresztą byłoby podobnie, gdyby ktoś powiedział, że polityka panuje nad bogami, gdyż rozporządza we wszystkim w państwie (polis).

$Z$ oryginału greckiego przełożyt Marian A. Wesoty 